DOI https://doi.org/10.30525/978-9934-588-81-5-2.7

\title{
СТРУКТУРНА ПЕРЕБУДОВА СЕЛЕЗІНКИ ТА ЗМІНИ БІОХІМІЧНИХ ПОКАЗНИКІВ КРОВІ ПРИ ДІЇ ГЛУТАМАТУ НАТРІЮ
}

\author{
Гарапко T. B. \\ кандидат медичних наук, доцент, \\ доцент кафедри анатомії людини \\ та гістології медичного факультету \\ ДВНЗ «Ужггородський начіональний університет» \\ м. Ужгород, Украӥна \\ Матешук-Вацеба Л. Р. \\ доктор медичних наук, професор, \\ завідувач кафедри нормальної анатомії \\ Львівський начіональний медичний університет \\ імені Данила Галищького \\ м. Львів, Украӥна

\section{Воробець В. В.} \\ асистент кафедри мікробіології, вірусології, епідеміології \\ з курсом інфекційних хвороб медичного факультету \\ ДВНЗ «Ужгородський начіональний університет» \\ м. Ужгород, Україна
}

Вступ. На сьогодні у продукти харчування навмисно додають понад 2500 добавок, щоб зберегти їх певні властивості та продовжити термін зберігання. Однією з найбільш широко використовуваних добавок як в Україні, так і всьому світі є глутамат натрію [1, с. 91; 2, с. 339]. Він підвищує апетит та підсилює смакові якості продуктів, що веде до збільшення кількості спожитої їжі за добу, спричиняючи висококалорійну дієту як в даному експерименті. Надходження в організм енергії в надлишковій кількості, призводить до метаболічних порушень, надмірної маси тіла та, як результат, ожиріння [3, с. 177]. Метаболічними характеристиками дії глутамату натрію є розвиток інсулінорезистентності, цукрового дабету, в крові низький рівень ліпопротеїдів високої щільності, високий рівень тригліцеридів, ознаки запалення та загального окислювального стресу [4, с. 55; 5, с. 6583; 6, с. 787]. Проте недостатньо вивченим залишається питання впливу глутамату натрію на лімфоїдні органи, зокрема селезінку. Селезінка належать до вторинних імунних органів, де відбувається антигензалежна проліферація та диференціація Т- і В-лімфоцитів. 
Мета дослідження. Вивчити гістологічні зміни структурних компонентів селезінки щурів. Вивчити зміни біохімічних показників крові через шість тижнів дії глутамату натрію.

Матеріал і методи дослідження. Дослідження проведено на 26 білих щурах репродуктивного віку (2,5-4,0 місяців) масою 120-245 г. Мікроанатомію структурних компонентів селезінки білих щурів за умов фізіологічної норми дослідили на 10 інтактних тваринах (перша група). Експериментальна група тварин (друга група) - 10 тварин, яких упродовж шести тижнів годували висококалорійною дієтою (ВКД). В кожній групі було 5 щурів-самців та 5 щурів-самок. Висококалорійна дієта досягалася завдяки тому, що в їжу додавали глутамат натрію в дозі 0,07 г/кг/добу маси тіла щура. Контролем слугували 6 білих щурів, які замість висококалорійної дієти отримували стандартний харчовий раціон віварію.

Результати дослідження. Як показали отримані результати дослідження, у тварин інтактної та контрольної груп, як свідчать наші гістологічні дослідження, будова селезінки відповідала видовій нормі. Морфологічна структура селезінки у групі контрольних щурів-самців та щурів-самок відповідала нормі для даного віку тварини і наприкінці досліджень відхилень від норми не спостерігалося. Зовні селезінка оточена сполучнотканинною капсулою, від якої всередину органа проростають перегородки - трабекули. Площа зрізів селезінки зайнята білою та червоною пульпою. Біла пульпа утворена лімфоцитами, плазмоцитами, макрофагами, дендритними та інтердигітатними клітинами. Стромою для них служить ретикулярна тканина. Скупчення цих клітин називаються лімфатичними вузликами або фолікулами. Червона пульпа представлена скупченням формених елементів крові, які розташовані або в оточенні ретикулярних клітин, або в системі судинних синусів.

Через шість тижнів експерименту як в щурів-самців так і в щурівсамок чітко диференціюється біла та червона пульпа. Спостерігається виснаження лімфоїдної тканини з прогресуванням атрофії переважно білої пульпи. Площа лімфоїдних вузликів та розміри їх центрів розмноження зменшуються. Перекладки потовщені, набряклі. Стінки деяких судин набряклі, просвіт заповнений елементами крові. Кількість моноцитів, макрофагів та плазмоцитів в паренхімі органа зростає. Залишки гемосидерину трапляються як в цитоплазмі макрофагів, так i в міжклітинних просторах. Присутність залізовмісного пігменту $\epsilon$ свідченням гибелі еритроцитів. Частка ретикулярної сполучної тканини в селезінкових тяжах зростає. Вени червоної пульпи повнокровні. Спостерігається імуноіндукуючий ефект з посиленою проліферацією активованих лімфоцитів та їх подальшим диференціюванням у плаз- 
матичні клітини. Навколо малих судин, виявляються еозинофільні агрегації та накопичення ліпідів у розширених пазухах.

Рівень глюкози в крові білих щурів інтактної групи становив $5,9 \pm 0,09$ ммоль/л у самців та 6,0 $\pm 0,08$ ммоль/л у самок. Через шість тижнів дії глутамату натрію рівень глюкози в крові збільшився до $8,65 \pm 0,1$ ммоль/л у самців та 8,35 $\pm 0,08$ ммоль/л у самок, що на 46,6 \% та 39,2 \% відповідно більше показника інтактних тварин.

Рівень АЛТ в крові білих щурів інтактної групи становив $76,5 \pm 0,2$ Од/л у самців та 67,5 $\pm 0,18$ Од/л у самок. Через шість тижнів дії глутамату натрію рівень АЛТ в крові зменшився до 72,8 $\pm 0,07$ Од/л у самців та 51,2 $\pm 0,08$ Од/л у самок, що на 4,8 \% та 24,1\% відповідно менше показника інтактних тварин.

Рівень АСТ в крові білих щурів інтактної групи становив $175,7 \pm 0,35$ Од/л у самців та $168,0 \pm 0,49$ Од/л у самок. Через шість тижнів дії глутамату натрію рівень глюкози в крові зменшився до $89,0 \pm 0,4$ Од/л у самців та 80,5 $\pm 0,41$ Од/л у самок, що на 49,3 та 52,1% відповідно менше показника інтактних тварин.

Висновки.

В результаті дослідження, проведеного на щурах самцях та самках, нами виявлено:

1. Шеститижневий вплив глутамату натрію призводить до виснаження лімфоїдної тканини з прогресуванням атрофії переважно білої пульпи. Площа лімфоїдних вузликів та розміри їх центрів розмноження зменшуються. Артерії з потовщеною стінкою, повнокровні, вени розширені та повнокровні. Синуси червоної пульпи розширені, гемосидерин та скопичення ліпідів у просвіті венозних пазух. Макрофаги наповнені краплями гемосидерину.

2. Рівень глюкози в крові зріс на 46,6 \% у білих щурів самців та на 39,2 \% у самок. Рівень АЛТ та АСТ зменшився на 4,8 \% та 49,3\% у самців, та на 24,1\% і 52,1\% у самок.

\section{Література:}

1. Krynytska I., Marushchak M., Naumova L., Mazur L. The Toxic Impact of Monosodium Glutamate in Rats. Jordan Medical Journal. 2019. Vol. 53 (2). P. 91-101.

2. Umukoro S., Oluwole G.O., Olamijowon H.E., Omogbiya A.I., Eduviere A.T. Effect of monosodium glutamate on behavioral phenotypes, biomarkers of oxidative stress in brain tissues and liver enzymes in mice. World J. of Neuroscience. 2015. Vol. 5. P. 339-349.

3. Afifi M.M., Abbas A.M. Monosodium glutamate versus diet induced obesity in pregnant rats and their offspring. Acta Physiol Hung. 2011. Vol. 98 (2), P. 177-188. 
4. Gobato A.O., Vasques A.C.J., Zambon M.P., Barros Filho A.A., Hessel G. Metabolic syndrome and insulin resistance in obese adolescents. Rev. Paul. Pediatr. 2014. Vol. 32 (1). P. 55-62.

5. Guo S.-X., Yan Y.-Z., Mu L.-T., Niu Q., He J., Liu J.-M., et al. Association of serum free fatty acids with hypertension and insulin resistance among rural uyghur adults in Far Western China. Int. J. Environ. Res. Public Health. 2015. Vol. 12 (6). P. 6582-6590.

6. Martos-Moreno G.A., Gil-Campos M., Bueno G., Bahillo P., Bernal S., Feliu A., et al. Obesity associated metabolic impairment is evident at early ages: spanish collaborative study. Nutr. Hosp. 2014. Vol. 30 (4). P. 787-793.

DOI https://doi.org/10.30525/978-9934-588-81-5-2.8

\title{
МОРФОЛОГІЧНІ ЗМІНИ СТІНКИ СЕЧОВОГО МІХУРА ПІД ДІЄЮ ДИМЕТИЛСУЛЬФОКСИНУ
}

\author{
Гончарук В. В. \\ аспірант кафедри нормальної анатомії
}

Вінницький національний медичний університет імені М. І. Пирогова

Костюк О. Г.

доктор медичних наук, професор,

завідувач кафедри променевої діагностики, променевої терапії і онкологї

Вінницький національний медичний університет імені М. І. Пирогова м. Вінниия, Украӥна

Рак сечового міхура (РСМ) відносять до найбільш частих злоякісних новоутворень, займаючи шосте місце серед чоловіків та 17 місце серед жінок в загальній структурі онкологічної захворюваності (WHO, Bladder cancer statistics, 2018). В Україні у 2018 році, за даними Національного канцерреєстру, рак сечового міхура в загальній структурі онкологічної захворюваності займає дев'яте місце. Рецидив ПРСМ це важлива не вирішена пороблена сьогодення [5]. Рецидиви ПРСМ призводять до зменшення ступеню диференціації пухлин, що в свою чергу призводить до розвитку IPCM [4]

У вітчизняній та іноземної наукової літератури, знайдено незначну кількість інформації про морфологічні зміни в слизовій оболонці стінки сечового міхура при застосуванні внутрішньоміхурової хіміотера36 